\title{
NEW SPHINGIDAE.
}

By the Hon. Walter Rothschild, Рн.D., and Karl JoRdan, Рн.D.

\section{Protoparce fosteri spec. nov.}

§. Close to P. lichenea Burm. (1856). No sharply defined line on mesothoracic tegula. Abdomen beneath pure white, mesial dots black; side-patches of tergites white, large. Pulvillus of claw-segments present, but small.

Wings, upperside.—Forewing narrower than in both lichenea and florestan; the interspaces between the black lines purer white; hairy patch at base restricted, more extended white; black longitudinal discal streaks $\mathrm{R}^{3}-\mathrm{M}^{2}$ rather longer than in lichenea ; first and second discal line heavy, merged together as in lichenea, interspace between second and third line white from costal to inner margin, the third line crenate, well marked ; interspace between third and fourth lines buffish white, especially the posterior portion of this interspace much purer buffish white than in the allied species; fifth line widened at costal margin to a large triangular patch; interspace between this patch and the oblique apical line buffish white. - Hindwing more elongate than in lichenea; white from base to first band, except a large patch between cell and $\mathrm{SM}^{2}$, this patch brown-black, continuous with the first band ; interspaces between the three brown-black bands white posteriorly, sharply defined, the white colour gradually shaded over with brown anteriorly, but the interspace remaining distinct to costal margin.

Underside.-Forewing deeper black-brown than in lichenea; cell more washed with grey; two rather distinct brown-black lines on disc, the interspace between them and a band at the distal side of the second line greyish white, distinct; submarginal area also more extended grey than in florestan and lichenea. -Hindwing : greyish-white ; a heavy black line tonching cell, curved basad on abdominal fold, more proximal behind than the corresponding line of the allied species; just outside this line a second one, dentate, rather thin, joining the first line at $\mathrm{M}^{1}$; a third line farther distad, thin, partly obsolescent between the veins, very strongly dentate ; marginal band well defined, about $5 \mathrm{~mm}$. broad in middle, paler brown-black than first line; interspace between the marginal band and the third line about as wide as the band.

Tenth tergite broader vertically than in the allied species. Harpe in shape similar to that of lichenea and florestan, rather smaller, emarginate ventrally, its edge slightly irregular, non-dentate. Tooth of penis-sheath longer than in the allied species.

Length of forewing: $64 \mathrm{~mm}$.

Hab. Sapucay, Paraguay, January 22, 1905 (W. Foster).

One $\delta$.

2. Euryglottis albostigmata basalis subspec. nov.

Euryglottis albostigmate Rothschild \& Jord., Nov. Zool. ix. Suppl. p. 98 (1903) (partim; S.E. Peru).

q. We received this form when our revision of the Sphingidae was in press. On comparing again typical $q$ of albostigmata we now find that the Peru 
individuals differ in the hindwing being all white from the base to the first discal line, the costal area excepted.

Hab. S. Domingo, Carabaya, S.E. Peru, 6000 ft., March 1901 (G. R. Ockenden).

Two $q$ ?

\section{Protambulyx xanthus spec. nov.}

§. Upperside: forewing as in P. eurycles Herr.-Sch. (1854), but posterior subbasal patch narrower, more oblique.-Hindwing: very pale chrome, paler than in eurycles and euryalus; lines as in euryalus R. \& J. (1903), but the first line broader, standing closer to cell, and the marginal band narrower.

Underside deep maize-yellow; discal lines faint, except the first which is strongly marked on both wings; marginal band of forewing as in eurycles, extending to hinder angle as in that species, being much wider between $R^{1}$ and $R^{2}$ than in euryalus, and tapering to a point, ending at tip of $\mathrm{SC}^{5}$.

Eighth sternite with short obtuse mesial lobe. Patch of friction-scales on clasper obliquely transverse, widest dorsally, similar to that of eurycles but longer.

Length of forewing: $60 \mathrm{~mm}$.

Hab. Tuis, Costa Rica.

One $\delta$.

Perhaps a northern form of eurycles. Easily distinguished from eurycles by the third line of the hindwing above being curved as in euryalus, sulphurea, and astygonus (see Nov. Zool. ix. Suppl. p. $176 \mathrm{ff}$.), differing from the latter insects especially in the marginal band of the forewing being shaped as in eurycles.

\section{Compsogene panopus celebensis subspec. nov.}

$\delta$. Forewing, above : interspace between subbasal band and patch of cellbars narrower at costal margin than in Malayan and Indian specimens, the proximal bar of that patch more straight and heavier ; brown marginal border symmetrical, evenly tapering at both ends, the black line bordering it non-dentate, the olive proximal border of this line much wider and much more evenly rounded; black discal band more oblique, almost parallel to margin, crossing subcostals distally of base of $\mathrm{SC}^{5}$.

Underside: the proximal subapical costal spot larger, the line extending from this spot to inner angle less distinct or vestigial ; marginal band almost evenly rounded, being much less strongly narrowed from $\mathrm{R}^{2}$ forward and backward.

Hab. Tondano and Sawangan, North Celebes.

Two pairs.

\section{Polyptychus anochus spec. nov.}

๙. Upperside of palpas, head and thorax grey, of abdomen buffish grey; underside pale vinaceous cinnamon; tibiae grey on upperside, the grey streak of midtibia sharply defined, interrupted before middle. Legs, palpus, and antenna similar to those of $P$. andosa Walk. (1856) in structure.

Wings, upperside.—Forewing: apex strongly produced, distal margin deeply concave below apex, convex behind middle, inner angle projecting backwards; pinkish grey, markings clayish vinaceous cinnamon; a broad antemedian band consisting of several lines with the interspaces filled in, narrower behind, about as broad as the grey median interspace; this interspace denticulate, being bordered by 
a thin brownish crenate line which curves costad; the whole area between this line and distal margin clayish vinaceous cinnamon, bearing a row of ill-defined and rather indistinct grey patches which are situated proximally of a second discal crenate line; this line extremely faint, being accentuated by vein-dots ; one small subbasal dot; stigma a small ring with grey centre-Hindwing pale salmonbuff, greyish at anal angle, indistinctly marked with brown; anal angle more produced than in $P$. andosa.

Underside clayish salmon-buff; two brown lines on disc of each wing, parallel, denticulate, curving costad.

Neuration : $\mathrm{SC}^{2}$ and $\mathrm{R}^{1}$ of hindwing on a very short stalk; $\mathrm{D}^{2}$ almost four times as long as $\mathrm{D}^{3}$, very oblique, slightly angulate; $\mathrm{D}^{3}$ a little shorter than $\mathrm{D}^{4}$; lower angle of cell acute.

Genitalia : tenth tergite very different from that of the other species of Polyptychus in being completely divided into two very slender, pointed processes, which stand widely separate; tenth sternite broken, apparently broad, roundedtruncate. Clasper with elongate-ovate friction-patch dorsally ; no friction-scales on inner side of eighth tergite; clasper strongly narrowed apicad, ending in an acute point which is bent downwards ; harpe with two processes ; one ventral, reversed, beak-shaped, being curved upwards and pointed ; the other much longer, irregnlarly triangular, obliquely longitudival, tapering, somewhat irregular, curved inward. No distinct armature on penis-sheath.

Length of forewing: $28 \mathrm{~mm}$.

Hab. Sierra Leone.

One $\delta$.

Similar in colour to P. andosa, compar, and consimilis (see Nov. Zool. ix. Suppl. p. 250), but widely different in the genitalia. Apex of forewing much more produced.

\section{Libyoclanis gen. nov.}

. Palpus much slenderer than in Clanis and Pseudoclanis, ${ }^{*}$ segments 1 and 2 nearly equal in length, the joint between them not open. Antenna cylindrical. Tibiae spinose at apex ; spurs much shorter than in allied genera mentioned; two pairs to hindtibia, the short spur a little shorter than the tibia is broad, half the length of the long one ; cell of hindwing truncate, both the upper and lower angles being about $90^{\circ} ; \mathrm{SC}^{2}$ and $\mathrm{R}^{1}$ on a short stalk.

Antevaginal ridge asymmetrical, produced into a process on each side, the processes being unequal in size.

Type : L. bainbridgei gen. nov.

Here belongs also Clanis bicolor, from Sierra Leone, $\dagger$ which we left provisionally in Clanis when revising the Splingidae.

\section{Libyoclanis bainbridgei spec. nov.}

. Body tawny olive above, wood-brown beneath, sides of abdomen somewhat creamy, with an ill-defined white patch at base, upperside of tibiae and tarsi mummy-brown, stiff hairs at tip of abdomen yellow.

* See Revision of Sphingidae, in Nov. Zool. ix. Suppl. p. 220 (1903).

† L.c. p. 219. 


\section{$(181)$}

Wings, upperside.—-Forewing produced at apex into a prominent lobe, which is about $5 \mathrm{~mm}$. long, measured from tip of $\mathrm{SC}^{5}$; greenish clay-colour (more green when alive?); two faint straight oblique parallel lines, greyish, the second a little beyond base of $\mathrm{M}^{2}$, the first about $6 \mathrm{~mm}$. distant from it, these lines being the proximal borders of indistinct clay bands, a pale band across cross-veins, from costal to inner margin, widest between $\mathrm{R}^{1}$ and $\mathrm{R}^{3}$, including a small transparent stigma bordered with brown; an oblique brown line from apex to $\mathrm{R}^{2}$, ending here in an indistinct brown patch; a small brown subapical patch at bend of costal margin preceded by a cloud of glossy grey scales; a small rosy red basal spot at inner margin.-_Hindwing rosy red, costal margin creamy white, distal margin tawny olive, this marginal band gradually widening behind and becoming paler, extending along abdominal margin to base, the hairs at base being creamy white.

Underside greenish buff, paler than upperside, ereamy towards base.Forewing rosy red centrally from base beyond apex of cell; a brown line from apex obliquely beyond $\mathrm{R}^{2}$. - Hindwing with large rosy red patch along abdominal margin ; two greenish yellow lines across disc, at $\mathrm{R}^{3}$ the distances between these lines, cell and distal margin, about equal; $\mathrm{R}^{2}$ from centre of cell.

Vaginal ridge raised into a triangular tooth on each side, the right tooth being longer and broader than the left one.

Length of forewing: $67 \mathrm{~mm}$.

Hab. Sierra Leone (Major Bainbridge).

One $q$.

We name this fine species in honour of the collector, from whom we have received several interesting captures.

\section{Pholus vitis fuscatus subspec, nov.}

Pholus vitis vitis, Rothschild \& Jord., Nov. Zool. ix. p. 494. n. 418. a. (1903) (partim; St. Vincent ; Grenada).

Having received a series of fresh specimens, we now propose a separate name for the form from the Lesser Antilles.

. Wings, upperside: pale markings of forewing more or less washed with brown, therefore less contrasting with the greenish olive-brown markings than in nearly all Continental specimens; subbasal band not distinctly edged with white; brown line situated within oblique grey discal band less distinct; marginal band broader, not edged with white.

Hab. Santa Lucia (S. Branch), type ; Grenada ; St. Vincent,

A series of $q q$.

\section{Deilephila placida salomonis subspec. nov.}

Deilephila placida placida Rothschild \& Jord., Nov. Zool. ix. Suppl. p. 512. n. 430. a. (1903) (partim; Guadalcanar and Florida).

ठ. More nniformly olive, the markings less prominent; subbasal patch of forewing, upperside, hardly deeper olive than the ground-colour ; median band less oblique than in $p l$. placida; its proximal edge less curved.

Hab. Solomon Islands; N. Georgia, type ; Choisenl; Guadalcanar; Florida, $4 \delta \sigma^{\circ}$, collected by A. S. Meek, 


\section{Temnora angulosa spec. nov.}

f. Body russet-brown above, tawny-olive beneath.—Wings, upperside: forewing russet-brown, this area sharply limited on dise, indented on the veins, dilated before and behind $\mathrm{R}^{3}$, reaching posteriorly to inner angle and costally a little beyond apex of cell; disc outside the russet-brown area fawn-colour, apex washed with mars-brown; a thin brown line ontside the basi-discal area, nearly following the curve of the outer edge of this area, which it joins behind $\mathrm{M}^{1}$; distal margin biconcave, strongly angulate at $\mathrm{R}^{2}$, the angle somewhat rounded.Hindwing mummy-brown, entire.

Underside tawny olive, washed with mummy-brown._-Forewing mummybrown in centre from base to disc; a faint line on disc; an equally faint line obliquely from apex, bordering a faint marginal band which is slightly deeper brown than the distal portion of the disc.-Hindwing with a faint denticulate line on disc, curved like distal margin, but standing farther away from it in front than behind.

Length of forewing: $32 \mathrm{~mm}$.

Hab. Luluaburg, Kassai, Congo Free State, September 1902 (Landbeck). One $\delta$.

\section{Xylophanes fosteri spec. nov.}

$\delta$. Head and thorax olive above, with a pinkish grey side-stripe extending from tip of palpus to apical edge of mesothoracical tegula, edged with white behind, a brownish grey mesial streak on thorax only ; a central line on tegula tawny; abdomen wood-brown above, greyish at base, clayish towards apex; this dorsal area bordered by an olivaceous line which somewhat widens basally; three indistinct dorsal lines ; underside creamy buff in middle, buff shaded with tawny at sides. Onter spur of midtibia half the length of the inner.

Wings, upperside.—Forewing wood-brown shaded with sepia-colonr; apex acnte, distal margin entire, concave below apex ; seven lines between cell and distal margin, first and second from inner margin to $\mathrm{R}^{2}$, heavy, more or less merged together, the second being continued costad, but the upper portion very thin, third line thin, fourth accentuated by minute vein-dots, the line distinct from $\mathrm{R}^{3}$ to apex of wing, fifth also distinct from $\mathrm{R}^{3}$ to apex, indistinct from $\mathrm{R}^{3}$ backwards, the upper portions of these two lines more or less contiguous, sixth feeble, seventh vestigial, lines 4 to 7 converging to tip of wing, lines 2 and 3 not reaching costal edge, disappearing in a pale wood-brown costal subapical space; a small black stigma ; outside apex of cell a brown cloud which is continued behind $\mathrm{R}^{2}$ to lines 4 and 5 ; a small blackish costal dot distally of subcostal fork, this dot being the costal portion of the first line._-Hindwing blackish brown; a dirty pinkish band on disc from anal angle to costal edge, which it does not quite reach, palest behind, being more or less washed with brown in front.

Underside pale ochraceous, with a faint tint of pink, irrorated with wood-brown.

Forewing brown centrally from base beyond apex of cell ; a row of conspicuous black-brown vein-dots parallel to margin, curving costad in front, between this row and the cell a more or less vestigial line; distal marginal area pale wood-brown, this border angulate at $\mathrm{R}^{2}$, reaching here the line of dots.-Hindwing: a woodbrown line at lower angle of cell, parallel to distal margin, curving costad in front, the line broad but rather faint; distally of this line and parallel with it a vestige of 


\section{( 183 )}

a second line and then a row of small but distinct dots; distal marginal band wood-brown, tapering behind, brown behind $\mathrm{M}^{2}$, the veins being more or less of the ground-colour.

Tenth tergite sinuate at apex, sternite long, with rounded apex. Harpe short, slender, taperiug, with the apex curved upwards; a few very minute teeth at tip. Penis-sheath with an oblique row of teeth, the central portion of the row situated on a slightly elevated ridge, the portions at the right situated at the edge of an obtuse short process. Friction-scales large.

Length of forewing: $\delta, 30 \mathrm{~mm}$. ; $\uparrow, 33 \mathrm{~mm}$.

Hab. Sapucay, Paraguay, February and October 1903 (W. Foster).

One pair.

Near X. turbata Edw. (1887) and robinsoni Grote (1865).

\section{Xylophanes dolius spec. nov.}

o. Body as in fosteri, pale buff beneath. Outer spur of midtibia less than half the length of inner.

Wings resembling in shape those of $X$. hydrata R. \& J. (1903). Upperside of forewing wood-brown, washed with olive, lines in the same position as in $X$. hydrata, fourth thin, deeper brown in npper half than the others, fifth vestigial between $\mathrm{R}^{2}$ and $\mathrm{M}^{2}$, ending anteriorly in a brown spot situated at apex; costal marginal area paler at apex than rest of wing; a rather large black stigma._ Hindwing : black-brown, with a narrow buff band from anal angle to costal margin, which it does not quite reach, being shaded with brown anteriorly.

Underside pale buff, somewhat pinkish on disc, irrorated with brown. Forewing black-brown centrally from base beyond apex of cell ; a rather heavy line just distally of lower angle of cell, somewhat incurved behind $\mathrm{M}^{1}$, thin in front, ending in a costal dot; parallel with this line a row of dots, the costal dot being situated halfway between first line and apex ; a marginal spot below tip of wing, produced discad into an oblique line ; a heavy marginal double spot $\mathrm{M}^{1}-\mathrm{SM}^{2}$; all these lines and spots deep brown.-Hindwing : a eurved line and a row of dots on disc ; distal margiń brown.

Clasper with about seven large friction-scales. Harpe very slender, curved upwards at apex, tapering, denticulate distally. Tenth tergite and sternite long, the latter with almost parallel sides and rounded apex.

Length of forewing : $31 \mathrm{~mm}$.

Hab. Zamora, Ecuador (O. T. Baron).

One $\delta$, somewhat faded.

\section{Xylophanes cosmius spec. nov.}

ð. Body as in $X$. amadis Stoll (1782); basal lateral patch of abdomen less distinct, quite gradually fading away; abdominal tergites irrorated with brown scales, without line or dots. External spur of midtibia one-third shorter than inner.

Wings, upperside.—Forewing : apex produced, distal margin obtusely denticulate, deeply concave below apex, strongly convex in middle; wood-brown, washed with green, costal marginal area, a triangular space at ontside of discal line from $\mathrm{R}^{2}$ to apex, and inner margin more distinctly green than rest of wing; three greenish brown lines in basal half, curved, not reaching inner margin, onter two close together; a black stigma, outside which there is a greenish black patch, 
transverse, rounded distally, straight proximally; a very conspicnous line from tip of wing to middle of inner margin, continued along the latter to base, apically more curved than in amadis, crossing $\mathrm{R}^{3}$ at one-third the distance from cell to outer margin, greenish black, edged with grey proximally; traces of two lines proximally of it, these additional lines accentuated at costal edge by a spot each; a submarginal row of black vein-dots ; fringe black at veins._- Hindwing black, a greenish buff band from anal angle to costal margin, which it does not reach, slightly incised at the veins ; distal margin narrowly green ; fringe spotted black at posterior veius.

Underside ochraceons salmon-buff, irrorated with brown; markings as in amadis, distal marginal band rather wider; black fringe-spots conspicnons on both wings.

Tenth tergite feebly spatulate, truncate; sternite triangular, with the apex rounded. Seven large friction-scales on clasper. Harpe slender, tapering, curved upwards at apex faintly denticulate at tip. Penis-sheath with a broad streak of numerous minute teeth on left side, the convex area on which this streak is sitnated rounded at apex and at right side produced into an obtuse process, which is as broad as long, being covered all over with teeth and being directed proximad.

Length of forewing: $40 \mathrm{~mm}$.

Hab. La Union, Rio Huacamayo, Carabaya, S.E. Pern, 2000 ft., November 1904, wet season (G. R. Ockenden).

One ơ.

\section{Xylophanes chiron lucianus subspec. nov.}

Xylophanes chiron chiron, Rothschild \& Jord., Nov. Zool. ix. Suppl, p. 699. n. 652. b. (1903) (partim; Sta. Lucia).

Having now seen several specimens from Santa Lucia, we find that this island is inhabited by a special subspecies, which, though similar to the one found in Jamaica, differs in several points.

$\uparrow$. Upperside of body and forewing green, as in ordinary Continental individnals of $X$. chiron chiron; a brown or black mesial patch anteriorly on mesonotum. External spur of midtibia a little shorter than internal.

Wings, upperside.—Forewing broader than in the Jamaica and Continental forms; a green vestigial line from apex, proximally of this line a row of transverse black-brown dots on the veins from $\mathrm{SC}^{5}$ to $\mathrm{M}^{2}$, followed at inner margin by a triangular black-brown patch as in the other forms, these vein-dots partly connected with one another by vestiges of a brown line ; no trace of a clayish patch either at costal margin or on disc.—Hindwing with three spots on disc, a fourth, anterior spot being faintly indicated; the anal and subanal spots as in the other forms.

Underside similar to that of the Continental subspecies. One heavy line on disc of forewing, the proximal line of the other two subspecies not being marked; brown proximal edge of marginal band heavy, the costal interspace between this band and the discal line wider than in the other forms.-Hindwing : a brown line on disc accentuated by vein-dots, a vestige of a second line close to cell ; marginal band as broad as in the Continental subspecies.

Hab. Santa Lucia (S. Branch).

Several $q$ \% . 
14. Xylophanes chiron cubanus subspec. nov.

Xylophanes chiron nechus, Rothschild \& Jord., l.c. p. 698. n. 651. a. (1903) (partim ; Cuba).

Fresh material from Cuba shows that there are several points of difference between Cuban and Continental specimens.

$\delta$. S Smaller than the Continental form; antenna pinkish; underside of body more rufous.

Wings, upperside._- Forewing proportionately shorter, the costal and discal clayish patches much smaller.—Hindwing: discal spots smaller, buffish.

Underside: on the whole more extended rufons; the costal discal luteous patches of the forewing more restricted, the latter patch replaced by a dot.

Hab. Holquin, Cuba (Tollin; Parish).

A small series.

15. Xylophanes pyrrhus spec. nov.

$\delta$ f. Closely resembling $X$. thyelia L. (1758). Mnch larger. Forewing, above: the pale band bearing the double line wider than in thyelia, the line bordering this band distally gradually widening from tip of wing to $\mathrm{R}^{3}$; distal margin less rounded than in thyelia.

Underside.—Forewing: with three lines across disc, the first heavy, curved in front, reaching costal margin about $4 \mathrm{~mm}$. beyond subcostal fork, the second and third thin, close together but separate, curving costad in front, more proximal than in thyelia, the third being at $\mathrm{SC}^{5}$ about $3 \mathrm{~mm}$. distant from oblique apical line ; posterior portion of third line slightly dentate, the lnteous streak standing at its distal side more irregular than in thyelia and thinner.-Hindwing: proximally of the double line a vestige of another line.

Length of forewing : 33 to $3 \pi \mathrm{mm}$.

Hab. S. Domingo, Carabaya, S.E. Peru (G. R. Ockenden), a long series ; Merida, Venezuela (Briceno), one $\delta$.

We have a series of $X$. thyelia from various places, the range extending from S.E. Peru to Colombia, and eastwards to the Guianas and Trinidad. 


\section{$2 \mathrm{BHL}$ Biodiversity Heritage Library}

Rothschild, Lionel Walter Rothschild and Jordan, Karl. 1906. "New

Sphingidae." Novitates zoologicae : a journal of zoology in connection with the Tring Museum 13, 178-185. https://doi.org/10.5962/bhl.part.22797.

View This Item Online: https://www.biodiversitylibrary.org/item/21926

DOI: https://doi.org/10.5962/bhl.part.22797

Permalink: https://www.biodiversitylibrary.org/partpdf/22797

\section{Holding Institution}

Natural History Museum Library, London

\section{Sponsored by}

Natural History Museum Library, London

\section{Copyright \& Reuse}

Copyright Status: Public domain. The BHL considers that this work is no longer under copyright protection.

This document was created from content at the Biodiversity Heritage Library, the world's largest open access digital library for biodiversity literature and archives. Visit BHL at https://www.biodiversitylibrary.org. 